\title{
Assessment of the global warming potential associated with the construction process of healthcare centres
}

Journal of Building Physics

(C) The Author(s) 2020 Article reuse guidelines: sagepub.com/journals-permissions DOI: I0.II77/I744259I209|4333 journals.sagepub.com/home/jen

(S)AGE

\author{
Justo García-Sanz-Calcedo' (D, \\ Nuno de Sousa Neves ${ }^{2}$ and \\ João Paulo Almeida Fernandes ${ }^{2}$
}

\begin{abstract}
The carbon footprint reveals the emission profile of a healthcare building and, when quantified properly, is useful for the design of effective mitigation plans. This article aims to determine the global warming potential associated with the healthcare centre building process in Spain at a 100-year perspective. To this end, six healthcare centres built between 2007 and 2010 were analysed, and the emissions associated with the manufacturing, transport and placement of materials on site - including the final tests and commissioning of the building - were calculated. The results show that the average $\mathrm{CO}_{2}$ equivalent emission per $\mathrm{m}^{2}$ built is $1122.30 \mathrm{~kg}$ (standard deviation $\left.=136.46\right), 1.24 \mathrm{~kg}($ standard deviation $=0.19$ ) per euro spent and $71.35 \mathrm{~kg}$ (standard deviation $=7.13$ ) per hour spent on construction. Emissions per user, worker, electrical power and energy consumed were also classified. The material manufacturing and installation stages generate the most emissions, and healthcare centres larger than $2000 \mathrm{~m}^{2}$ appear to emit less $\mathrm{CO}_{2}$ equivalent per $\mathrm{m}^{2}$ when being built than smaller centres. The construction elements that caused most greenhouse gas emissions were also identified. These parameters allow extracting and designing proposals for improvements in environmental management.
\end{abstract}

\footnotetext{
'Engineering Projects Section, Department of Graphical Expression, University of Extremadura, Badajoz, Spain

${ }^{2}$ Department of Paisagem, Ambiente e Ordenamento, University of Evora, Evora, Portugal
}

\section{Corresponding author:}

Justo García-Sanz-Calcedo, Engineering Projects Section, Department of Graphical Expression, University of Extremadura, 06006 Badajoz, Spain.

Email: jgsanz@unex.es 


\section{Keywords}

Carbon dioxide emissions, building design, building engineering, healthcare buildings, building sustainability

\section{Introduction}

Climate change mitigation requires management strategies that reduce greenhouse gas (GHG) emissions, with the calculation of the carbon footprint being the most appropriate tool for quantifying these emissions (Vidal et al., 2015). Heavily used buildings - such as hospitals and healthcare centres - consume a significant proportion of the world's resources, mainly in the form of materials. In the European Union (EU), buildings account for $40 \%$ of energy consumption and emit $36 \%$ of total GHGs (European Commission, 2019). Energy use and emissions in buildings are also expected to double or even triple by the middle of this century (Lucon et al., 2014).

However, with efforts focused on reducing the building's operational energy consumption, the emissions embodied in the construction of buildings will foreseeably follow an inverted path and increase in the future (Yeo et al., 2016). The reason behind this is that the reduction in operating energy is sometimes associated with an increase in the emissions embodied in the building caused by the use of materials that consume comparatively more energy in their manufacture, although achieving savings in the operating phase (Ramesh et al., 2010). Efforts should, therefore, be geared around assessing emissions generated in the building construction process, as well as their better management, as a preliminary measure to shifting to a circular economy (Fang et al., 2017).

Healthcare centres are specifically designed to provide primary healthcare services linked to promoting, preventing, care and rehabilitation, which differ from hospitals in that the former are not for hospitalisation or surgeries (García-SanzCalcedo et al., 2018). Their design, construction and maintenance must take into account the impact of the facilities on their workers' productivity and patients' recovery (Reay et al., 2017). Healthcare centres have special facilities, many of which must be redundant, to ensure uninterrupted operation $24 \mathrm{~h}$ a day, every day of the week, increasing the total emission potential.

Several authors have used the life cycle assessment (LCA) as a tool to determine the carbon footprint and assess the environmental performance of buildings (Lemay, 2011; Bribián et al., 2009; Horne et al., 2009). Biswas (2014), for instance, calculated the carbon footprint and assessed the embodied energy consumption of the construction works of a university building in Australia, and found that there are opportunities for mitigating GHG in the life cycle of construction process and used materials. GHG emissions associated with construction could potentially be reduced by $7 \%$. However, none of these authors determined the global warming potential (GWP) of the different typologies of buildings studied in this research. 
Solís-Guzmán et al. (2013) developed a methodology for determining the ecological footprint of the construction of residential buildings in Andalusia (Spain) and applied it to the case study of the urbanisation and construction of a representative building type during the building's planning phase. However, Fenner et al. (2018) reviewed existing methodologies to account for the carbon footprint and described the inconsistencies of most carbon LCA studies. Both concluded that there is a need for an accessible and consistent method to assess buildings' carbon emissions (either in the construction as in the operation phases).

Kuittinen (2015), for his part, proposed a method to control the growth of buildings' carbon footprint during the preparation, design and acquisition phases of building projects by estimating costs, although he did not determine the effective $\mathrm{CO}_{2}$ emissions susceptible to be generated in the construction process. Shafiq et al. (2015) assessed the carbon footprint of a low-rise office building in Malaysia, using the building information modelling (BIM) software and concluded that a significant reduction in the building's carbon footprint is possible with the right choice of building materials. Bastianoni et al. (2006) assessed the environmental pressure generated by the construction of two types of buildings in Italy, through the carbon footprint analysis and revealed that there is a lower environmental pressure in multi-storey buildings than in single-storey buildings.

In this context, given the proven influence of materials on a building's GWP, their impact on the construction of every type of buildings and its evaluation for the case of healthcare centres should, therefore, be quantified.

Eckelman and Sherman (2016) studied the environmental impact of the US Healthcare System and the effects on public health. Seifert et al. (2019), on their side, categorised existing research on LCA-based approaches used to examine hospital products and processes. They found that most studies focused on the carbon footprint, comparing alternatives and identifying environmental impacts and hotspots, but did not consider the environmental impact related to the hospital global construction process.

Other authors have tried to quantify the $\mathrm{CO}_{2}$ equivalent $\left(\mathrm{CO}_{2} \mathrm{e}\right)$ emissions, based on the GWPs provided by the Intergovernmental Panel on Climate Change (IPCC) for each GHG (Solomon et al., 2007), of some types of buildings. Monahan and Powell (2011) found that a three-bedroom town house used 34.6 tonnes of $\mathrm{CO}_{2} \mathrm{e}$ or $405 \mathrm{~kg} \mathrm{CO} 2 / \mathrm{m}^{2}$ of usable floor space. Chastas et al. (2018) analysed 95 residential buildings to identify the range of carbon emissions and quantified them between 179.3 and $1050 \mathrm{~kg} \mathrm{CO} 2 \mathrm{e} / \mathrm{m}^{2}$, with a proportion between $9 \%$ and $80 \%$ of the total life cycle impact. De Wolf et al. (2017) identified the barriers for the effective construction $\mathrm{CO}_{2}$ measurement using focus groups and interviews with experts and obtained results between 200 and $1700 \mathrm{~kg} \mathrm{CO} \mathrm{CO}_{2} \mathrm{e} / \mathrm{m}^{2}$. Pöyry et al. (2015) assessed GHG emissions of the building phase of a low-energy residential building at $470 \mathrm{~kg}$ $\mathrm{CO}_{2} \mathrm{e} / \mathrm{m}^{2}$. The results of all these authors differ significantly from one another, and the presented intervals are excessively high.

Therefore, quantifying the emissions of the construction of a building is complex and consumes more resources than measuring operating energy (Dixit, 2017). 
There is no precedent for studies assessing and quantifying the total GWP of the construction process of a healthcare centre using a statistically representative sample of healthcare buildings.

This research aims to calculate the GWP after the construction process of healthcare centres in Spain and propose emission indicators based on different operational variables typical of this type of buildings. A period of 100 years was chosen because, among the optional IPCC ranges, it was the most appropriate for Spanish buildings (Solomon et al., 2007). The stages that cause most of the GHG emissions in the construction of healthcare centres are identified, and improvements can indeed be made in its prevention through adequate environmental management. Emission indicators will also be available for benchmarking in the design and drafting process of healthcare centre projects to progressively limit $\mathrm{CO}_{2}$ emissions in future projects. Assessing the carbon footprint of the construction process of a healthcare centre will also improve the design and decision-making phase processes, as it can be used to review sustainability initiatives throughout the building's life cycle and choose the right materials to be used in its construction.

This article is structured into five sections: section 'Introduction' describes the introduction of this study, section 'Methodology' describes methods used in this study, section 'Results' presents the result obtained in this study, section 'Discussion' gives the discussion on practical implications and finally, section 'Conclusion' draws the conclusion of this article.

\section{Methodology}

Six health centres located in the region of Extremadura (Spain), designed between 2006 and 2009 and built between 2007 and 2010, were analysed in the frame of this study. The buildings were selected for being representative of the construction materials used, the means used in the construction, the location and type of construction and that they had similar facilities: heating, ventilation and air conditioning (HVAC), domestic hot water (DHW), cold water for human consumption (CWHC), electricity and so on. Healthcare centres were selected to be statistically representative in terms of construction area $\left(1300-3200 \mathrm{~m}^{2}\right)$, the number of users $(6500-18,000)$ and the thermo-hygrometric conditions of their location. The features of the healthcare centres studied here are outlined in Table 1.

All projects of the selected healthcare centres were drafted under the same Spanish legal regulations. Specifically, the most significant rules were the Technical Building Code (Ministerio de Fomento, 2006) and the Regulation on Thermal Installations in Buildings (Ministerio para la Transición Ecológica, 1998). All the buildings analysed had similar energy performance certificates.

Each healthcare centre was visited to verify that what had been built coincided with the detailed design and ensure the accuracy of the analysed data. All the buildings had been built with a reinforced concrete structure and unidirectional slabs, braced footing, air conditioning with heat pumps, high level of thermal insulation, 
Table I. Analysed healthcare centres.

\begin{tabular}{llllll}
\hline Centre & Built area $\left(\mathrm{m}^{2}\right)$ & Users & Workers & Construction year & Number of storeys \\
\hline 1 & 1515.39 & 13,359 & 22 & 2009 & 1 \\
2 & 1328 & 4700 & 16 & 2007 & 2 \\
3 & 2824.40 & 17,844 & 40 & 2009 & 2 \\
4 & 3191.67 & 14,951 & 34 & 2008 & 2 \\
5 & 2366.50 & 16,500 & 22 & 2009 & 1 \\
6 & 1877.40 & 6984 & 19 & 2008 & 1 \\
\hline
\end{tabular}

inverted roof, aluminium carpentry with double glazing, terrazzo flooring, smooth plastic paint on walls, and transformation centre with medium voltage connection and generating set.

The GHG emissions of each healthcare centre were analysed in two steps. First, the total gases produced in each process were calculated, and then these gases were converted to $\mathrm{CO}_{2} \mathrm{e}$. The amount of $\mathrm{CO}_{2} \mathrm{e}$ emissions was calculated based on the GWPs provided by IPCC for each GHG (Solomon et al., 2007). The GWP for a gas is a measure of the magnitude of climate change caused by a unit of that gas over a given period (100 years) relative to that caused by a unit of $\mathrm{CO}_{2}$. The conversion coefficients shown in Table 2 were used.

A simplified analysis was carried out to calculate the life cycle of GHG emissions. The recycling of construction materials or their disposal in landfills was not considered following ISO 14040:2006 (2006) standards. Therefore, the emissions associated with demolition and transport to landfill were not considered, and the analysis was limited to three phases: the production of construction materials, the supply of materials and the building phase, including the final tests and commissioning of each healthcare centre.

The functional variables used here were the built area $\left(\mathrm{m}^{2}\right)$, the number of users (No), the number of workers in each healthcare centre (No), execution cost $(€)$, total number of hours used in construction $(\mathrm{h})$, electrical power installed $(\mathrm{kW})$ and annual energy consumption ( $\mathrm{kWh}$ ).

The construction material supply phase included the amount of GHG emissions associated with their extraction, processing and production. Transport included the movement of workforce and materials to and from the site. The building phase included the GHG emissions associated with the entire healthcare centre construction process, including final testing and commissioning of the facilities.

The BEDEC database of the Construction Technology Institute of Catalonia (Instituto de Tecnología de la Construcción (ITEC), 2019) was used to determine $\mathrm{CO}_{2}$ emissions. The amount of $\mathrm{CO}_{2}$ emissions of each construction material was obtained using the detailed budgets of each project which are included as a basic document of each of the building projects. The building materials were inventoried 
Table 2. 100-year GHG conversion coefficients.

\begin{tabular}{ll}
\hline Gas $(\mathrm{kg})$ & GWP I00 years $\left(\mathrm{kg} \mathrm{CO} \mathrm{CO}_{2} \mathrm{e}\right.$ \\
\hline $\mathrm{CO}_{2}$ & $\mathrm{I}$ \\
$\mathrm{CH}_{4}$ & 23 \\
$\mathrm{~N}_{\mathbf{x}} \mathrm{O}$ & 296 \\
$\mathrm{HFC}-23$ & 12,000 \\
$\mathrm{HFC}-125$ & 3400 \\
$\mathrm{HFC}-134 \mathrm{a}$ & 1300 \\
$\mathrm{HFC}-143 \mathrm{a}$ & 4300 \\
$\mathrm{CF} 4$ & 5700 \\
$\mathrm{C}_{2} \mathrm{~F}_{6}$ & 11,900 \\
$\mathrm{SF}_{6}$ & 22,200 \\
\hline
\end{tabular}

GHG: greenhouse gas; GWP: global warming potential.

according to the detailed design, and the used amount of each material was discretely calculated and classified by construction activities.

An emission of $0.788 \mathrm{~kg}$ of $\mathrm{CO}_{2} \mathrm{e} / \mathrm{m}^{3}$ of water used was considered (FloresSánchez, 2018), as well as a different distance from the $8 \mathrm{~m}$ connection with a structured polyvinyl chloride (PVC) pipe for the connections of the general sewerage network. The average of Spain's 2018 energy mix (group of different primary energy sources from which secondary energy is produced) was used to calculate the GHG emissions associated with the electrical and thermal energy used in the building process. $0.249 \mathrm{~kg}$ of $\mathrm{CO}_{2} \mathrm{e}$ was estimated for each $\mathrm{kWh}$ (Electricitymap, n.d.).

All the transformer substations were prefabricated, including a three-phase oilbath transformer of nominal power proportional to the installed electrical receivers, with an electrical reserve of $25 \%$. The most important power tools used in the building were a crane tower $(11 \mathrm{~kW})$, a concrete mixer $(0.55 \mathrm{~kW})$, a pump $(22 \mathrm{~kW})$, a concrete vibrator $(2.3 \mathrm{~kW})$ and an electric hammer $(1.4 \mathrm{~kW})$. In addition, loader, dump truck, backhoe, bulldozer, vibratory roller and manual mechanical tamper were used.

The total number of working hours and the effective duration of the building projects were obtained to determine the number of workers participating in the work. A site manager, a project manager, an administrative assistant and guard were also regarded as indirect workforce in the construction process. It was also taken for granted that workers have a meal during their working day, with an average $\mathrm{CO}_{2}$ emission of $3.85 \mathrm{~kg}$ of $\mathrm{CO}_{2} \mathrm{e}$.

For the determination of emissions related to worker mobility, it was assumed that the building site is located in an area far from the city centre, with no access to urban transport and the average daily distance travelled by vehicles was estimated at $30 \mathrm{~km}$. The average occupancy per vehicle was estimated at four persons. It was assumed that all vehicles for transporting materials use diesel and those for 
Table 3. $\mathrm{CO}_{2}$ equivalent emissions per kilometre travelled and means of transport.

\begin{tabular}{ll}
\hline Transport & Emissions $\left(\mathrm{kg} \mathrm{CO}_{2} \mathrm{e} / \mathrm{km}\right)$ \\
\hline Motorcycles & 0.0904 \\
Cars & 0.1507 \\
Vans $<7.5$ tonnes & 0.3169 \\
Trucks $7.5-16$ tonnes & 0.4864 \\
Trucks $16-32$ tonnes & 0.6589 \\
Trucks $>32$ tonnes & 0.7876 \\
\hline
\end{tabular}

transporting workers use 95 octane petrol. Table 3 shows the equivalent carbon dioxide emissions per kilometre travelled, according to the means of transport used.

Table 4 shows the average distances travelled by the materials used in the building of a healthcare centre.

\section{Results}

The following are the results obtained by the research process.

\section{Analysis of the carbon footprint by building phase}

Table 5 shows the average percentage impact, standard deviation and percentiles of total $\mathrm{CO}_{2} \mathrm{e}$ emissions of a healthcare centre, classified by building phase. The phase that generates more carbon footprint in the building of healthcare centres is the manufacture and installation of the embodied building materials $(96.12 \%)$ followed by transport $(1.52 \%)$.

\section{Analysis of the carbon footprint per functional unit}

Table 6 shows the average, standard deviation and percentiles of each of the indicators analysed in the study, specifically $\mathrm{CO}_{2} \mathrm{e}$ emissions per unit area $\left(\mathrm{m}^{2}\right)$, per euro used in the building process $(€)$, per number of health centre users (No), per number of workers, per average annual energy consumption $(\mathrm{kWh})$, per installed electrical power $(\mathrm{kW})$ and per hour of work used in the building phase.

The most appropriate indicators are $\mathrm{CO}_{2} \mathrm{e}$ emissions per unit area, per euro invested and per hour of work used in the construction process, as these are the ones with the lowest percentage of standard deviation. Indicators based on installed electrical power or average annual energy consumption cannot be applied until the building is in use. Indicators based on the number of users and the number of workers have high variability and are not suitable for reference use. 
Table 4. Average distance travelled by materials used in the building process.

\begin{tabular}{ll}
\hline Materials & Distance $(\mathrm{km})$ \\
\hline Concrete and aggregates & 40 \\
Ceramic & 60 \\
Steel & 50 \\
Sanitation & 90 \\
Carpentry & 200 \\
HVAC & 400 \\
Electrical installation & 350 \\
Waste (to landfill) & 15 \\
\hline
\end{tabular}

HVAC: heating, ventilation and air conditioning.

Table 5. Percentage impact by phase of work on the total carbon footprint of a healthcare centre.

\begin{tabular}{|c|c|c|c|c|c|c|c|}
\hline \multirow[t]{2}{*}{ Phase } & \multirow[t]{2}{*}{$\%$} & \multirow{2}{*}{$\begin{array}{l}\text { Standard } \\
\text { deviation }\end{array}$} & \multicolumn{5}{|c|}{ Percentiles } \\
\hline & & & $10 \%$ & $25 \%$ & $50 \%$ & $75 \%$ & $90 \%$ \\
\hline $\begin{array}{l}\text { Manufacture and installation } \\
\text { of materials }\end{array}$ & 96.12 & 0.0052 & 95.56 & 95.64 & 96.10 & 96.50 & 96.71 \\
\hline Transport of workforce & 0.34 & 0.0006 & 0.27 & 0.29 & 0.34 & 0.40 & 0.42 \\
\hline Transport of materials & 1.18 & 0.0021 & 0.98 & 1.08 & 1.13 & 1.25 & 1.42 \\
\hline Electricity and machinery fuel & 1.48 & 0.0033 & 1.22 & 1.24 & 1.27 & 1.69 & 1.94 \\
\hline Food for the workforce & 0.71 & 0.0015 & 0.59 & 0.64 & 0.66 & 0.76 & 0.90 \\
\hline Final tests & 0.09 & 0.0002 & 0.07 & 0.07 & 0.08 & 0.09 & 0.11 \\
\hline Commissioning & 0.08 & 0.0002 & 0.06 & 0.07 & 0.07 & 0.09 & 0.10 \\
\hline
\end{tabular}

Table 6. Carbon emission indicators per functional unit.

\begin{tabular}{|c|c|c|c|c|c|c|c|}
\hline \multirow[t]{2}{*}{ Ratio } & \multirow[t]{2}{*}{ Average } & \multirow{2}{*}{$\begin{array}{l}\text { Standard } \\
\text { deviation }\end{array}$} & \multicolumn{5}{|c|}{ Percentiles } \\
\hline & & & $10 \%$ & $25 \%$ & $50 \%$ & $75 \%$ & $90 \%$ \\
\hline $\mathrm{kg} \mathrm{CO} \mathrm{CO}_{2} \mathrm{e} \mathrm{m}^{2}$ & 1122.30 & 136.46 & 981.17 & 1017.80 & 1084.73 & 1228.83 & 1301.00 \\
\hline $\mathrm{kgCO} 2 \mathrm{e} / €$ & 1.24 & 0.19 & 1.06 & 1.08 & 1.15 & 1.40 & 1.49 \\
\hline $\mathrm{kg} \mathrm{CO} 2 \mathrm{e}$ /users & 215.33 & 85.90 & 129.90 & 153.35 & 188.37 & 290.51 & 327.70 \\
\hline $\mathrm{kg} \mathrm{CO} 2 \mathrm{e} /$ workforce & $97,327.90$ & $17,519.14$ & $80,411.79$ & $90,368.28$ & $92,212.91$ & $108,257.30$ & $119,359.00$ \\
\hline $\mathrm{kg} \mathrm{CO} 2 \mathrm{e} / \mathrm{kWh}$ & 11.25 & 1.65 & 10.14 & 10.38 & 10.57 & 11.09 & 13.05 \\
\hline $\mathrm{kg} \mathrm{CO} 2 \mathrm{e} / \mathrm{kW}$ & 4813.44 & 469.36 & 4435.27 & 4515.35 & 4649.16 & 4888.33 & 5355.89 \\
\hline $\mathrm{kg} \mathrm{CO} 2 \mathrm{e} / \mathrm{h}$ & 71.35 & 7.13 & 62.58 & 66.36 & 72.53 & 74.76 & 78.94 \\
\hline
\end{tabular}


Table 7. Emissions and average consumption per unit area per work typology.

\begin{tabular}{|c|c|c|c|c|c|c|c|}
\hline \multirow{2}{*}{$\begin{array}{l}\text { Construction } \\
\text { activities }\end{array}$} & \multirow{2}{*}{$\begin{array}{l}\text { Average } \\
\left(\mathrm{kg} \mathrm{CO} 2 \mathrm{e} / \mathrm{m}^{2}\right)\end{array}$} & \multirow{2}{*}{$\begin{array}{l}\text { Standard } \\
\text { deviation } \\
\left(\mathrm{kg} \mathrm{CO}_{2} \mathrm{e} / \mathrm{m}^{2}\right)\end{array}$} & \multicolumn{5}{|c|}{ Percentiles } \\
\hline & & & $10 \%$ & $25 \%$ & $50 \%$ & $75 \%$ & $90 \%$ \\
\hline $\begin{array}{l}\text { Earthwork, sanitation } \\
\text { and foundations }\end{array}$ & 172.02 & 74.57 & 106.13 & 121.38 & 146.79 & 210.06 & 248.01 \\
\hline Structure and roof & 455.03 & 60.22 & 398.22 & 416.06 & 445.81 & 489.39 & 515.53 \\
\hline $\begin{array}{l}\text { Masonry, insulation } \\
\text { and carpentry }\end{array}$ & 355.69 & 82.25 & 283.27 & 299.73 & 327.17 & 397.39 & 439.53 \\
\hline Facilities & 94.75 & 15.11 & 79.73 & 89.26 & 105.13 & 105.43 & 105.61 \\
\hline $\begin{array}{l}\text { Windows, painting } \\
\text { work, urbanisation } \\
\text { and miscellaneous }\end{array}$ & 47.22 & 27.44 & 19.25 & 34.31 & 59.40 & 66.22 & 70.31 \\
\hline
\end{tabular}

\section{Analysis of the carbon footprint per construction activities}

Table 7 shows the emissions and average consumption per unit area, classified by construction activities of the building project of each healthcare centre.

Figure 1 shows the average percentage of $\mathrm{CO}_{2} \mathrm{e}$ emissions according to the type of work carried out on site.

The structure and the roof generate more $\mathrm{CO}_{2} \mathrm{e}$ emissions, followed by masonry work, thermal insulation, wall and ceiling cladding and carpentry (doors and windows). Among the two phases, $70 \%$ of the emissions are exceeded in the building process of a healthcare centre. Some installations (HVAC, DHW, CWHC, etc.) have proven to only account for $8.42 \%$ of emissions during the building phase.

The average direct workforce employed in the healthcare centres in the sample was analysed by specialities and is shown in Figure 2. The average direct workforce per unit area was $16.35 \mathrm{~h} / \mathrm{m}^{2}$ (standard deviation $(\mathrm{std})=2.5$ ) and the indirect was $1.19 \mathrm{~h} / \mathrm{m}^{2}(\mathrm{std}=0.19)$.

\section{Analysis by building elements}

The construction activities that caused most of the GHG emissions were identified. Figure 3 shows them sorted by construction activities.

The structure, the masonry, the foundations and the roof are the activities of the healthcare centre building project that generate more $\mathrm{CO}_{2} \mathrm{e}$ emissions per $\mathrm{m}^{2}$. By work unit, the transformer centre, the air conditioning heat pump and the generating set are, in this order, the equipment that emit the most significant amount of $\mathrm{CO}_{2} \mathrm{e}$ in their manufacture, assembly and commissioning, followed by aluminium carpentry. However, considering the total measurement, the structure, the roof, the enclosures, the brick partition walls and the aluminium carpentry generate the most $\mathrm{CO}_{2} \mathrm{e}$ emissions in the building project as a whole. Reinforced concrete has the largest proportion of total GHG emissions. However, although the 


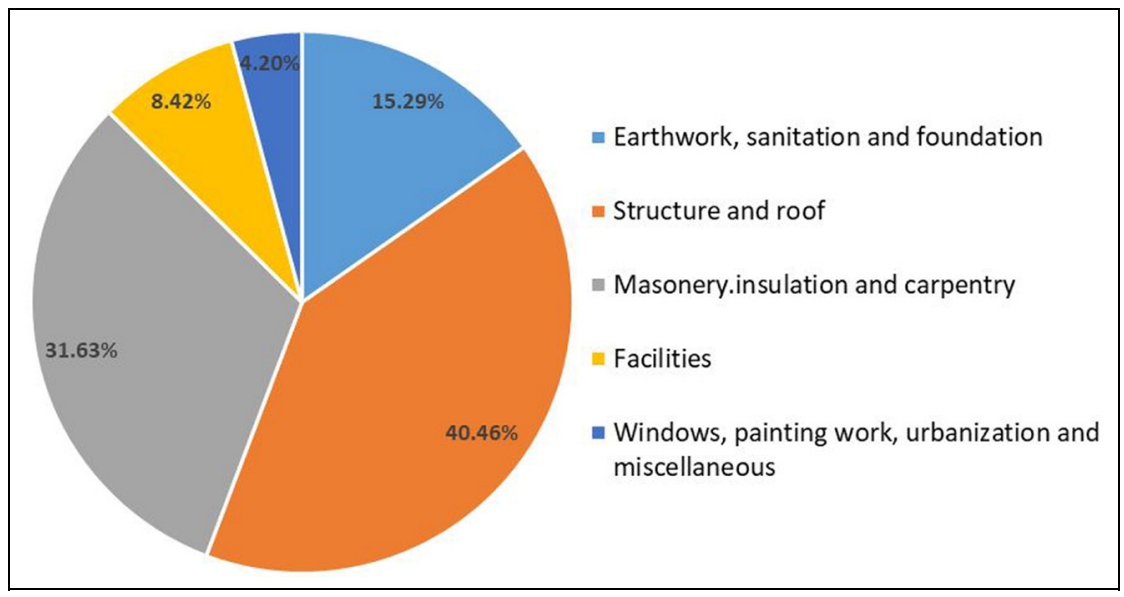

Figure I. Average $\mathrm{CO}_{2}$ e emissions grouped by project work typologies.

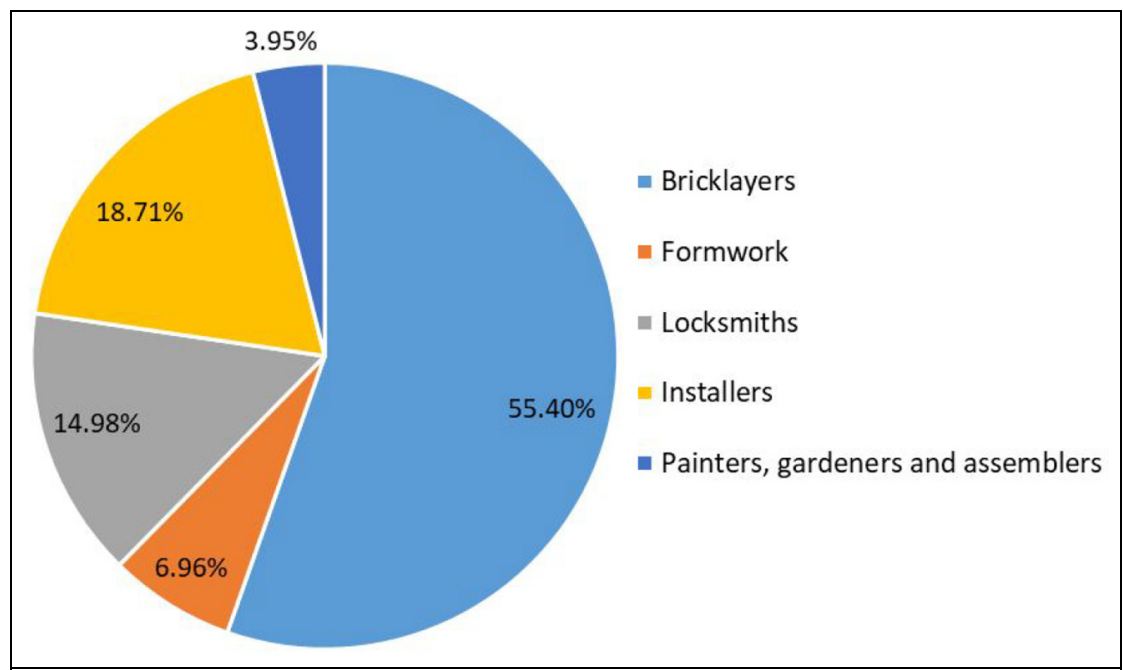

Figure 2. The average direct workforce employed in the healthcare centres in the sample, classified by specialities.

installations constitute one of the parts of the building that generate the most emissions in the use phase, they have a much more limited weight in the building phase.

As for transformer centres, The emission represented by the electric transformers are $6700 \mathrm{~kg}$ of $\mathrm{CO}_{2} \mathrm{e}$ for those cooled with mineral oil and $4222 \mathrm{~kg}$ of $\mathrm{CO}_{2} \mathrm{e}$ for dry 


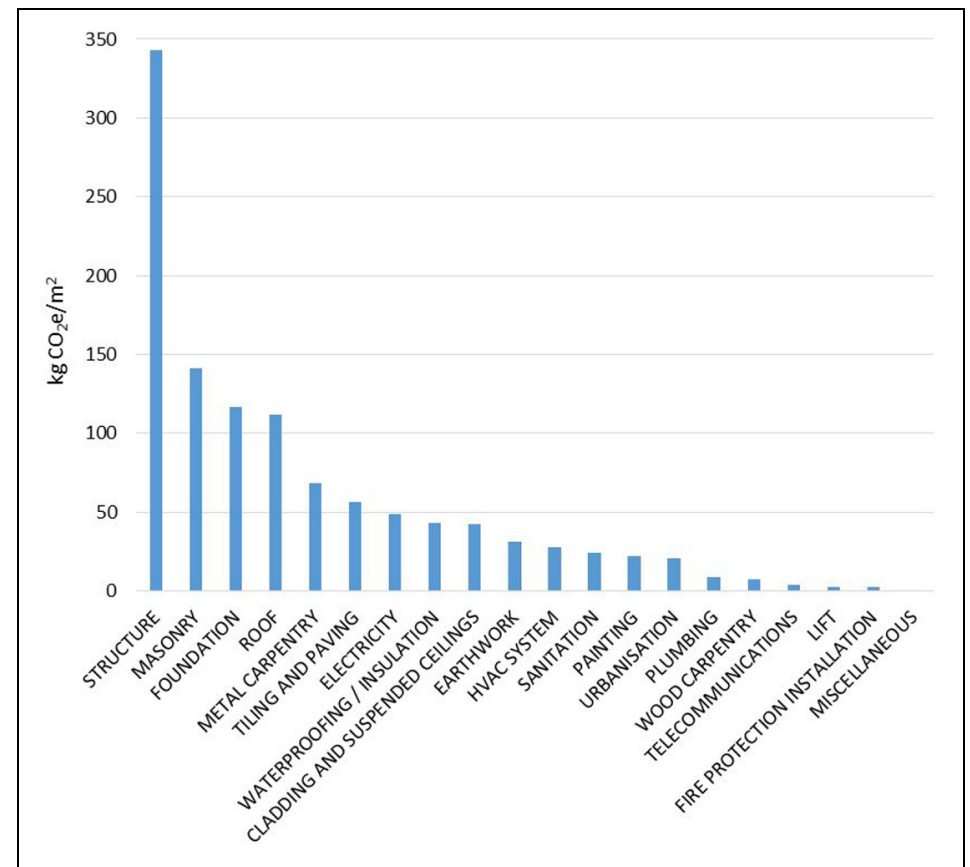

Figure 3. GHG emissions of each construction activity.

cooling, which added to the $4770 \mathrm{~kg}$ of $\mathrm{CO}_{2} \mathrm{e}$ involved in the manufacture and distribution of the cells, form the items with the highest emission.

\section{Statistical analysis}

The results obtained from the statistical analysis of variance (ANOVA), which studies the relationship between $\mathrm{CO}_{2} \mathrm{e}$ emissions in the building phase of healthcare centres and the variables analysed, are presented below. The following hypotheses were drawn in the analysis:

Null hypothesis $\left(H_{0}\right)$. The variables analysed are not related to the $\mathrm{CO}_{2} \mathrm{e}$ emissions of a healthcare centre.

Alternative hypothesis $\left(H_{1}\right)$. The variables analysed are related to the $\mathrm{CO}_{2} \mathrm{e}$ emissions of a healthcare centre.

The $p$ value was compared with the level of significance to determine whether any of the differences between the averages of the studied factors are statistically significant and to assess the null hypothesis. A level of significance of 5\% (95\% confidence interval) was considered for this study. If the $p$ value is less than or equal to 
the level of significance, that is, $p \leqslant 0.05$, the null hypothesis can be rejected, and it could be concluded that not all population means are equal. Otherwise, if the value of $p$ is higher than the level of significance, there is not enough evidence to reject the null hypothesis. The Snedecor's $F$-test was carried out to obtain the statistical significance.

It was found that healthcare centres larger than $2000 \mathrm{~m}^{2}$ emit less $\mathrm{CO}_{2} \mathrm{e} / \mathrm{m}^{2}$ of built area in their building process than centres with less than $2000 \mathrm{~m}^{2}(F=14.61$; $p=0.01873)$. The rest of the indicators proposed in Table 6 were verified accordingly, but no significant statistical differences were found.

It was also demonstrated that the centres with building investment greater than $€ 2,000,000$ have fewer emissions per $\mathrm{m}^{2}$ than the centres with investment less than $€ 2,000,000(F=10.695 ; p=0.0307)$, although no significant differences were found between the investment per unit area and $\mathrm{CO}_{2} \mathrm{e}$ emissions per $\mathrm{m}^{2}(F=0.0196$; $p=0.8951)$.

\section{Discussion}

Healthcare centres generate more emissions in their construction processes than other buildings in the tertiary sector; this is because they have more sophisticated installations, their structure has greater spans, the enclosures have better thermal insulation and the material used in interior finishes is prepared for greater intensity of use.

There are also grounds to say that to determine the GWP of a healthcare centre, the most suitable functional unit is the constructed area $\left(\mathrm{m}^{2}\right)$. The construction stage of a healthcare building is not usually assessed by the number of users and workers from an environmental perspective. However, these indicators are necessary to determine the environmental impact in the use phase, and therefore, they have been included as results of this research. Emissions per euro invested in the construction process have also shown to be an appropriate indicator to measure the GWP. The $\mathrm{CO}_{2} \mathrm{e}$ emissions per hour of labour embedded in the building process are also considered adequate, as it indicates the intensity of labour and the degree of industrialisation of the building process. However, the $\mathrm{CO}_{2} \mathrm{e}$ emissions per energy and installed power depend on use factors, which render their use not advisable.

Transport accounts for only $1.52 \%$ of total GHG emissions in the building phase. The impact of transporting goods and workers can be reduced using collective means of transport and hybrid or electric vehicles on journeys. A suitable measure is to organise the purchase and stockpiling of material policy to optimise transport, which could also be carried out in larger trucks making fewer trips. In other words, subcontractors could agree to share trucks and reduce trips; this forces gathering material on site, but substantially reduces the number of trips and, therefore, the associated emissions. 
The mission of circular economy is to be an alternative that reuses and designs products that can be reused again, with a lower energy consumption than in the first process, also using renewable energy systems. Taking this aspect into account in the construction of healthcare centres, GHG emission rates can be substantially reduced (Pomponi and Moncaster, 2017).

The material manufacture and installation phase generates the most carbon footprint in the building of healthcare centres. Therefore, the correct choice of materials in the design phase is critical when it comes to minimise the healthcare centre's carbon footprint. These materials must be selected appropriately, with strategies that can reduce GHG emissions of the project, without increasing the financial burden on the contractor or causing delays in the project schedule (Tang et al., 2013). The selection of materials for a healthcare centre must also take into account the impact they generate on the maintenance of the building (Burak Gunay et al., 2019) and must not be conditioned by aesthetic or functional issues.

The literature provides mitigation strategies to reduce the carbon footprint of materials used in a building: the use of fly ash cement in concrete formulations and replacement of new aluminium with recycled aluminium, the replacement of new steel with recycled steel (Damgaard et al., 2009), the use of flat roofs (CarreteroAyuso and García-Sanz-Calcedo, 2018) and the optimisation of lift shafts (GarcíaSanz-Calcedo and Pena Corpa, 2014). Sustainable gardens with tall trees can mitigate the building's environmental impact; for example, 1 hectare of pine trees can capture more than 7.22 tonnes of $\mathrm{CO}_{2}$ (Ramírez et al., 2012). It is also convenient to use local materials, manufactured close to the building site. The correct labelling of materials used during the building process (Wu et al., 2014) - including GHG emissions and energy embedded in their manufacture - should also be mandatorily considered in the design phase.

Since the research showed that concrete and structural steels are the most polluting elements in the construction stage, it is important to minimise their use by optimising the calculations and providing technical solutions that reduce the amount of those materials (McElroy and Rosenow, 2019), thus avoiding building structure oversize.

Installations must also be selected according to their $\mathrm{CO}_{2}$ emissions at the project phase. The emissions in the construction and use phases of the building must be considered. For example, the use of low GWP refrigerant gases can reduce the global carbon footprint of a healthcare centre (Devecioğlu and Oruç, 2015). According to legal regulations, new installations must incorporate equipment with low GWP refrigerant fluids, for example, R32 (Mota-Babiloni et al., 2017). The over-dimensioning of equipment and the redundancy of installations significantly increase environmental emissions. However, it is essential to guarantee the resilience of this building in the event of emergencies or natural disasters.

The impact of the final tests and functional tests is reduced and helps to optimise the commissioning of the building. Commissioning processes are recommended to ensure the correct start-up of a healthcare centre (Lord et al., 2016). The convenience or not of renovating or making new healthcare buildings under the proposed 
methodology should be assessed to determine the environmental impact of the building process (Alba-Rodríguez et al., 2017).

The legislation should incorporate a maximum limit on $\mathrm{CO}_{2}$ emissions and other GHGs in the construction processes and not as is presently the case of the Spanish regulations that only limit the atmospheric emissions that the building will produce in the use phase. This would favour an optimised choice of building materials with less environmental impact already in the design phase.

The results can be extrapolated to other types of buildings with similar facilities and quality of materials and also to other countries of the European environment since they have similar legal regulations and construction techniques.

Future work should focus on analysing the carbon footprint and impact of operating and use healthcare centres, and on calculating the effect of users' and workers' means of transport in this phase as well of management practices.

\section{Conclusion}

The GWP associated with the healthcare centres construction process was assessed, and it was concluded that the most appropriate indicators to determine the average GWP of a healthcare centre are: $1122.30 \mathrm{~kg}$ of $\mathrm{CO}_{2} \mathrm{e}$ per $\mathrm{m}^{2}$ built, $1.24 \mathrm{~kg}$ of $\mathrm{CO}_{2} \mathrm{e}$ per euro spent on the building process and $71.35 \mathrm{~kg}$ of $\mathrm{CO}_{2} \mathrm{e}$ per hour of work used. Emissions per user, worker, electrical power and energy consumed were also classified. These indicators are suitable for benchmarking in the design process and drawing up healthcare centre projects, and for progressively limiting $\mathrm{CO}_{2}$ emissions in future projects.

The choice of materials is a key task when building a healthcare centre, as it was found that the phase that generates the greatest carbon footprint in the building process is the material manufacturing and installation phase $(96.12 \%)$ followed by transport $(1.52 \%)$. The calculations proved that concrete, with an emission of $235.56 \mathrm{~kg}$ of $\mathrm{CO}_{2} \mathrm{e} / \mathrm{m}^{3}$, together with steels, with $4.28 \mathrm{~kg}$ of $\mathrm{CO}_{2} \mathrm{e} / \mathrm{kg}$, are the most polluting items. Healthcare centres larger than $2000 \mathrm{~m}^{2}$ emit less $\mathrm{CO}_{2} \mathrm{e} / \mathrm{m}^{2}$ in their building process than smaller centres.

The construction of the structures of healthcare centres is the predominant task in terms of $\mathrm{CO}_{2} \mathrm{e}$ emissions, with an average emission of $343.88 \mathrm{~kg}$ of $\mathrm{CO}_{2} \mathrm{e} / \mathrm{m}^{2}$. Also of great importance are roofs and masonry, with an average emission of $120.6 \mathrm{~kg}$ of $\mathrm{CO}_{2} \mathrm{e} / \mathrm{m}^{2}$ of roof and $141.37 \mathrm{~kg}$ of $\mathrm{CO}_{2} \mathrm{e} / \mathrm{m}^{2}$, respectively. These three activities account for approximately $75 \%$ of total emissions in the construction phase, while earthworks, sanitation and foundations represent $15 \%$, installations represent $8 \%$, and the rest of the work typologies do not reach $5 \%$ of the total.

\section{Acknowledgements}

The authors express their appreciation to the Spanish Ministry of Science, Innovation and Universities (José Castillejo Programme) for the financial assistance to assistant professor 
J.G.-S.-C. during his stay at the University of Evora (Portugal), for the development of a part of this study.

\section{Declaration of conflicting interests}

The author(s) declared no potential conflicts of interest with respect to the research, authorship and/or publication of this article.

\section{Funding}

The author(s) disclosed receipt of the following financial support for the research, authorship and/or publication of this article: This work was supported by the European Social Fund through Research Projects GR18029 linked to the VI Regional Plan for Research, Technical Development and Innovation from the Regional Government of Extremadura (2017-2020).

\section{ORCID iD}

Justo García-Sanz-Calcedo (iD https://orcid.org/0000-0003-4449-2636

\section{References}

Alba-Rodríguez MD, Martínez-Rocamora A, González-Vallejo P, et al. (2017) Building rehabilitation versus demolition and new construction: economic and environmental assessment. Environmental Impact Assessment Review 66: 115-126.

Bastianoni S, Galli A, Niccolucci V, et al. (2006) The ecological footprint of building construction. In: Mander U, Brebbia CA and Tiezzi E (eds) The Sustainable City IV: Urban Regeneration and Sustainability. Southampton: WIT Press, 345-356.

Biswas WK (2014) Carbon footprint and embodied energy consumption assessment of building construction works in Western Australia. International Journal of Sustainable Built Environment 3(2): 179-186.

Bribián ZI, Usón AA and Scarpellini S (2009) Life cycle assessment in buildings: state-ofthe-art and simplified LCA methodology as a complement for building certification. Building and Environment 44(12): 2510-2520.

Burak Gunay H, Shen W and Yang C (2019) Text-mining building maintenance work orders for component fault frequency. Building Research \& Information 47(5): 518-533.

Carretero-Ayuso MJ and García-Sanz-Calcedo J (2018) Comparison between building roof construction systems based on the LCA. Journal of Construction 17(1): 123-136.

Chastas P, Theodosiou T, Kontoleon KJ, et al. (2018) Normalising and assessing carbon emissions in the building sector: a review on the embodied $\mathrm{CO}_{2}$ emissions of residential buildings. Building and Environment 130: 212-226.

Damgaard A, Larsen AW and Christensen TH (2009) Recycling of metals: accounting of greenhouse gases and global-warming contributions. Waste Management \& Research 27: 773-780.

De Wolf C, Pomponi F and Moncaster A (2017) Measuring embodied carbon dioxide equivalent of buildings: a review and critique of current industry practice. Energy and Buildings 140: 68-80. 
Devecioğlu AG and Oruç V (2015) Characteristics of some new generation refrigerants with low GWP. Energy Procedia 75: 1452-1457.

Dixit MK (2017) Life cycle embodied energy analysis of residential buildings: a review of the literature to investigate embodied energy parameters. Renewable and Sustainable Energy Reviews 79: 390-413.

Eckelman MJ and Sherman J (2016) Environmental impacts of the U.S. Health Care System and effects on public health. PLOS ONE 11(6): e0157014.

Electricitymap ( n.d.) Available at: https:/www.electricitymap.org/?page = country\&solar $=$ false $\&$ remote $=$ true $\&$ wind $=$ false $\&$ countryCode $=$ ES (accessed 30 July 2019).

European Commission (2019) Available at: https://ec.europa.eu/energy/en/topics/energyefficiency/energy-performance-of-buildings (accessed 30 July 2019).

Fang K, Dong L, Ren J, et al. (2017) Carbon footprints of urban transition: tracking circular economy promotions in Guiyang, China. Ecological Modelling 365: 30-44.

Fenner AE, Kibert CJ, Woo J, et al. (2018) The carbon footprint of buildings: a review of methodologies and applications. Renewable and Sustainable Energy Reviews 94: 1142-1152.

Flores-Sánchez R (2018) Balance energético y de emisiones de dióxido de carbono de una planta de reciclado de fosfoyeso. PhD Thesis, University of Seville, Seville.

García-Sanz-Calcedo J, Al-Kassir A and Yusaf T (2018) Economic and environmental impact of energy saving in healthcare buildings. Applied Sciences 8(3): 440.

García-Sanz-Calcedo J and Pena Corpa S (2014) Comparativa entre sistemas constructivos de huecos para ascensores en función del ACV. Dyna 89(1): 98-105.

Horne R, Grant T and Verghese K (2009) Life Cycle Assessment: Principles, Practice and Prospects. Collingwood, VIC, Australia: CSIRO Publishing.

Instituto de Tecnología de la Construcción (ITEC) (2019) Banco ITEC2019. Datos Ambientales [Environmental Data]. Barcelona: ITEC.

ISO 14040:2006 (2006) Gestión ambiental-Evaluación del ciclo de vida-Principios y marco.

Kuittinen M (2015) Setting the carbon footprint criteria for public construction projects. Procedia Economics and Finance 21: 154-161.

Lemay L (2011) Life cycle assessment of concrete buildings. Concrete Sustainability report, CSR04. Silver Spring, MD: National Ready Mixed Concrete Association.

Lord S-F, Noye S, Ure J, et al. (2016) A comparative review of building commissioning regulation: a quality perspective. Building Research \& Information 44(5-6): 630-643.

Lucon O, Ürge-Vorsatz D, Ahmed A.Z. et al. (2014) Buildings Climate Change 2014: Mitigation of Climate Change. Contribution of Working Group III to the Fifth Assessment Report of the Intergovernmental Panel on Climate Change. Cambridge; New York: Cambridge University Press.

McElroy DJ and Rosenow J (2019) Policy implications for the performance gap of lowcarbon building technologies. Building Research \& Information 47(5): 611-623.

Ministerio de Fomento (2006) Código Técnico de la Edificación de España. Madrid: Gobierno De España.

Ministerio para la Transición Ecológica (1998) Reglamento de Instalaciones Térmicas en los Edificios. Madrid: Gobierno De España.

Monahan J and Powell JC (2011) An embodied carbon and energy analysis of modern methods of construction in housing: a case study using a lifecycle assessment framework. Energy and Buildings 43(1): 179-188. 
Mota-Babiloni A, Navarro-Esbrí J, Makhnatch P, et al. (2017) Refrigerant R32 as lower GWP working fluid in residential air conditioning systems in Europe and the USA. Renewable and Sustainable Energy Reviews 80: 1031-1042.

Pomponi F and Moncaster A (2017) Circular economy for the built environment: a research framework. Journal of Cleaner Production 143: 710-718.

Pöyry A, Säynäjoki A, Heinonen J, et al. (2015) Embodied and building phase greenhouse gas emissions of a low-energy residential building. Procedia Economics and Finance 21: 355-365.

Ramesh T, Prakash R and Shukla KK (2010) Life cycle energy analysis of buildings: an overview. Energy and Buildings 42(10): 1592-1600.

Ramírez NFF, Del Carmen Mendizábal-Hernández L and Alba-Landa J (2012) Potencial de Captura y Almacenamiento de $\mathrm{CO} 2$ en el Valle de Perote. Estudio de caso: Pinus cembroides subsp. Orizabensis DK Bailey. Foresta Veracruzana 14(1): 17-22.

Reay S, Collier G, Kennedy-Bueno J, et al. (2017) Designing the future of healthcare together: prototyping a hospital co-design space. CoDesign 13(4): 227-244.

Seifert C, Koep L, Wolf P, et al. (2019) Life cycle assessment as a decision support tool for environmental management in hospitals: a literature review. Health Care Management Review. Epub ahead of print 20 May. DOI: 10.1097/HMR.0000000000000248.

Shafiq N, Fadhil Nurrudin M, Safdar Gardezi SS, et al. (2015) Carbon footprint assessment of a typical low-rise office building in Malaysia using building information modelling (BIM). International Journal of Sustainable Building Technology and Urban Development 6(3): 157-172.

Solís-Guzmán J, Marrero M and Ramírez-de-Arellano A (2013) Methodology for determining the ecological footprint of the construction of residential buildings in Andalusia (Spain). Ecological Indicators 25: 239-249.

S Solomon, D Qin, M Manning, et al. (eds) (2007) Intergovernmental Panel on Climate Change Fourth Assessment Report of 2007. Cambridge; New York: Cambridge University Press.

Tang P, Cass D and Mukherjee A (2013) Investigating the effect of construction management strategies on project greenhouse gas emissions using interactive simulation. Journal of Cleaner Production 54: 78-88.

Vidal R, Moliner E, Pikula A, et al. (2015) Comparison of the carbon footprint of different patient diets in a Spanish hospital. Journal of Health Services Research \& Policy 20(1): $39-44$.

Wu P, Xiao B, Pienaar J, et al. (2014) The past, present and future of carbon labelling for construction materials-a review. Building and Environment 77: 160-168.

Yeo Z, Ng R and Song B (2016) Technique for quantification of the embodied carbon footprint of construction projects using probabilistic emission factor estimators. Journal of Cleaner Production 119: 135-151. 